\title{
HETEROMORPHA ARBORESCENS: A REVIEW OF ITS BOTANY, MEDICINAL USES, AND PHARMACOLOGICAL PROPERTIES
}

\author{
ALFRED MAROYI* \\ Department of Botany, Medicinal Plants and Economic Development Research Centre, University of Fort Hare, Private Bag X1314, Alice \\ 5700, South Africa. Email: amaroyi@ufh.ac.za
}

Received: 17 August 2018, Revised and Accepted: 18 September 2018

\begin{abstract}
Heteromorpha arborescens is an important medicinal plant species throughout its distributional range in tropical Africa. This study evaluated the botany, medicinal uses, and pharmacological activities of H. arborescens. Literature focusing on the botany, phytochemical, pharmacological, and toxicological properties of $\mathrm{H}$. arborescens were obtained from scientific databases such as SCOPUS, Science Direct, PubMed, SciFinder, Medline, and Google Scholar. Pre-electronic literature sources such as book chapters, books, journal articles, conference papers, and other scientific documents were obtained from the University library. Literature search revealed that H. arborescens is used as an aphrodisiac, as herbal medicine for shortness of breath, intestinal worms, inflammation, pain, respiratory problems, skin infections, headache, fever, and malaria. Pharmacological studies of compounds and H. arborescens extracts revealed anthelmintic, antiarthritic, antibacterial, antifungal, anti-inflammatory, antimycobacterial, antinociceptive, antioxidant, antipeptic ulcer, anti-scabies, antispasmodic, antiviral, cytotoxicity, genotoxicity, and uterotonic activities. More detailed research is needed aimed at assessing phytochemical, pharmacological, and toxicological properties of different plant parts and phytochemical compounds isolated from the species.
\end{abstract}

Keywords: Apiaceae, Heteromorpha arborescens, Traditional medicine, Tropical Africa.

(C) 2018 The Authors. Published by Innovare Academic Sciences Pvt Ltd. This is an open access article under the CC BY license (http://creativecommons. org/licenses/by/4. 0/) DOI: http://dx.doi.org/10.22159/ajpcr.2018.v11i11.29108

\section{INTRODUCTION}

Heteromorpha arborescens (Spreng.) Cham. and Schltdl. is a large shrub, small or medium deciduous tree which belongs to the carrot and parsley or Apiaceae family. Van Wyk [1] listed the stems of $H$. arborescens as commercially relevant medicinal and aromatic component of herbal medicines in east and southern Africa as aphrodisiac, for hypertension and headache. In a previous study, Van Wyk [2] argued that the essential oil of $H$. arborescens is important in the development of new pharmaceutical and health products in southern Africa for headache, inhalant, and aromatherapy. In Southern Africa, the leaves, roots, and bark of the species are used to treat abdominal pains, asthma, colic, cough, dysentery, fever, headaches, infertility, intestinal worms, mental problems, nervous disorders, shortness of breath, and tuberculosis [3-5]. Based on its popularity as traditional medicine in tropical Africa, $H$. arborescens is included in the monographic treatment of "medicinal plants of South Africa" [6], providing an overview of important medicinal plants in the country. The leaves and roots of $H$. arborescens are sold in informal herbal medicine markets in Botswana [7], Malawi [8], and South Africa [9]. Leaves of H. arborescens are eaten as vegetables in Kenya [10] while the roots of the species are fed to malnourished children in Botswana [7] and Swaziland [11]. It is within this context that the current study was carried out aimed at reviewing the botany, medicinal uses, phytochemical, and pharmacological properties of $H$. arborescens so as to provide baseline data required for assessing the therapeutic potential of the species.

\section{BOTANICAL DESCRIPTION OF H. ARBORESCENS}

H. arborescens is a member of the Heteromorpha Charm. and Schltdl. genus consisting of predominantly woody trees, shrubs, or suffrutices. The genus consists of seven species restricted to temperate and subtropical Africa and southern Yemen [12]. Calviño et al. [13] argued that the genus is monophyletic taxon based on analyses of ITS only or when using combined ITS and cpDNA data sets and the African species share the woody habit with the related genus Polemannia Eckl. and Zeyh. as well as fruit characters with the genus Polemanniopsis
B. L. Burtt which are regarded as sister genera to Heteromorpha [12]. $H$. arborescens is a straggling, open-branched shrub, or small- to medium-sized deciduous tree, up to $15 \mathrm{~m}$ in height $[12,14]$. The species has been recorded in several areas including fringing evergreen forest, where it reaches its greatest size, wooded ravines, hillsides, rocky outcrops, wooded grassland, bushveld, and forest margins [14,15]. The bark is satiny smooth, glossy, coppery brown, somewhat waxy in appearance, and peels off horizontally in papery flakes $[14,15]$. Leaves are simple to variously compound, varying even on the same branch and thinly textured. The flowers of the species are small, greenishwhite, or yellowish in color, occurring in dense round heads or compound umbels $[14,15]$. The fruits are small, dry, pale brown, and slightly winged capsules held in round clusters [16].

$H$. arborescens is very variable over its distributional range and has been split into five infraspecific taxa based on leaf and fruit morphology and also whether the taxa is a shrub which is rarely taller than $2 \mathrm{~m}$ or typically a tree with height ranging from 2 to $15 \mathrm{~m}[12,15]$. The infraspecific taxa are var. abyssinica (A. Rich.) H. Wolff, var. arborescens, var. collina (Eckl. and Zeyh.) Sond., var. frutescens Winter and Van Wyk, and var. montana Winter $[12,15]$. The majority of literature sources do not separate $H$. arborescens into infraspecific taxa, but $H$. arborescens sensu lato is widely used, and this is the name that has been adopted in this study. Synonyms of $H$. arborescens are Bupleurum collinum (Eckl. and Zeyh.) D. Dietr., Buprestis arborescens Spreng., Franchetella arborescens (Spreng.) Kuntze, H. arborescens var. collina (Eckl. and Zeyh.) Sond., H. collina Eckl. and Zeyh., H. trifoliate sensu Cufod., H. trifoliata (H.L. Wendl.) Eckl. and Zeyh., and Tenoria arborescens (Spreng.) Spreng. [12,15,17-28].

\section{MEDICINAL USES OF H. ARBORESCENS}

The different plant parts of $H$. arborescens including the bark, charcoal, leaves, milky exudate, roots, and root bark are used as herbal medicines in tropical Africa (Table 1). The major medicinal uses of $H$. arborescens recorded in at least three countries (in descending order of importance) 
Table 1: Medicinal uses of Heteromorpha arborescens in tropical Africa

\begin{tabular}{|c|c|c|c|}
\hline Medicinal use & Parts of the plant used & Country & References \\
\hline $\begin{array}{l}\text { Inflammation and pain (painful joints, } \\
\text { rheumatism, abdominal, general body, } \\
\text { and back pains) }\end{array}$ & Bark, leaves, and roots & $\begin{array}{l}\text { Malawi, South Africa, Swaziland, and } \\
\text { Zimbabwe }\end{array}$ & {$[3-6,11,29-32]$} \\
\hline Aphrodisiac & Roots and root bark & $\begin{array}{l}\text { Botswana, Malawi, Mozambique, } \\
\text { South Africa, and Zimbabwe }\end{array}$ & {$[3,4,33]$} \\
\hline Aphrodisiac & $\begin{array}{l}\text { Roots took by mouth mixed with } \\
\text { those of Carissa spinarum L. and } \\
\text { Xylopia parviflora (A. Rich.) Benth }\end{array}$ & South Africa & [29] \\
\hline $\begin{array}{l}\text { Respiratory problems (asthma, chest } \\
\text { pains, coughs, and tuberculosis) }\end{array}$ & Bark, charcoal, leaves, and roots & $\begin{array}{l}\text { Kenya, Lesotho, South Africa, and } \\
\text { Zimbabwe }\end{array}$ & {$[3-6,16,30,32,34-37]$} \\
\hline Blood purifier & Leaves and roots & South Africa & {$[3,16]$} \\
\hline Purifying blood & Leaves and roots & South Africa & [6] \\
\hline $\begin{array}{l}\text { Skin infections (boils, measles, ringworm, } \\
\text { and scabies) }\end{array}$ & Bark, leaves, and roots & $\begin{array}{l}\text { Kenya, Rwanda, South Africa, and } \\
\text { Tanzania }\end{array}$ & {$[33,38-40]$} \\
\hline Cancer & Roots & Zimbabwe & [4] \\
\hline Colic & Bark and leaves & South Africa & {$[3,6,32]$} \\
\hline Depressed fontanelles & Bark and roots & South Africa & [3] \\
\hline Diabetes & Leaves and roots & South Africa and Tanzania & {$[42,43]$} \\
\hline Shortness of breath & Leaves and roots & Botswana, Eritrea, and South Africa & {$[3,6,44,45]$} \\
\hline Dysentery and stomach problems & Bark, leaves, and roots & South Africa & {$[3,6,16,32,36,46]$} \\
\hline Dysmenorrhea & Roots & South Africa & {$[47]$} \\
\hline Fever and malaria & Bark and leaves and roots & $\begin{array}{l}\text { Malawi, South Africa, Uganda, } \\
\text { Tanzania, and Zimbabwe }\end{array}$ & {$[4,6,16,32,36,48-50]$} \\
\hline Fungal infections & Roots & Tanzania & {$[42]$} \\
\hline Gonorrhea & Milky exudate & Ethiopia & {$[51]$} \\
\hline Headache & Bark, charcoal, leaves, and roots & $\begin{array}{l}\text { Eritrea, Kenya, Lesotho, South Africa, } \\
\text { Swaziland, and Zimbabwe }\end{array}$ & $\begin{array}{l}{[3-6,11,16,29,31,32,34-} \\
36,45,46,52,53]\end{array}$ \\
\hline Heart problems & Roots & Botswana & {$[44]$} \\
\hline Induce appetite & Roots & South Africa & [33] \\
\hline Infertility & Roots, bark, and leaves & Zimbabwe and South Africa & {$[4,6,32,36,46,54]$} \\
\hline Intestinal worms & Leaves and roots & Lesotho, South Africa, and Swaziland & {$[3,6,11,16,30,35,36]$} \\
\hline Jaundice & Leaves and roots & Ethiopia & {$[55]$} \\
\hline Kidney problems & Leaves and roots & South Africa & {$[6,16,56]$} \\
\hline Peptic ulcers & Roots and root bark & Kenya and Zimbabwe & {$[56,57]$} \\
\hline Rabies & Leaves and roots & Ethiopia & {$[55]$} \\
\hline Snakebite & Roots & Ethiopia & [58] \\
\hline $\begin{array}{l}\text { Ethnoveterinary medicine (colic, gall } \\
\text { sickness, Redwater, threadworms, } \\
\text { tuberculosis, and vermifuge) }\end{array}$ & Bark & South Africa & {$[3,59,60]$} \\
\hline
\end{tabular}

include shortness of breath, intestinal worms, inflammation and pain, respiratory problems, aphrodisiac, skin infections, fever and malaria, and headache (Fig. 1). In multitherapeutic applications, the roots of H. arborescens are taken by mouth mixed with roots of Carissa spinarum L. and Xylopia parviflora (A. Rich.) Benth. as an aphrodisiac [29].

\section{PHYTOCHEMISTRY AND PHARMACOLOGICAL PROPERTIES}

Villegas et al. [61] isolated falcarindiol and sarisan from the leaves of H. arborescens. These two compounds exhibited antifungal activities and falcarindiol has analgesic effects which may account for the treatment of abdominal pain and headaches [6]. Recio et al. [62] identified 163,23-dihydroxy-13,28-epoxyolean-11-en-3 $\beta$-yl-[ $\beta$-D-glucopyranosyl $(1 \rightarrow 2)]$-[ $\beta$-D-glucopyranosyl $(1 \rightarrow 3)]-\beta$-D-fucopyranoside and $16 \beta, 23,28$ trihydroxy-11 $\alpha$-methoxyolean-12-en-3 $\beta$-yl-[ $\beta$-D-glucopyranosyl $(1 \rightarrow 2)]$-[ $\beta$-D-glucopyranosyl $\quad(1 \rightarrow 3)]-\beta$-D-fucopyranoside which exhibited anti-inflammatory activities from the leaves of $H$. arborescens. Makungo and van Ree [63] isolated an anti-inflammatory compound 6,7-dimethoxy-2H-chromen-2-one from the leaves and branches of $H$. arborescens. The volatile oil of $H$. arborescens is known to contain sabinene, $\delta$-3-carene, myrcene, germacrene-D, limonene, (Z)- $\beta$ ocimene, $\beta$-phellandrene, and $\alpha$-pinene as major constituents $[64,65]$ (Table 2). The volatile oil of $H$. arborescens exhibited antibacterial and antifungal activities against several microbes [66].

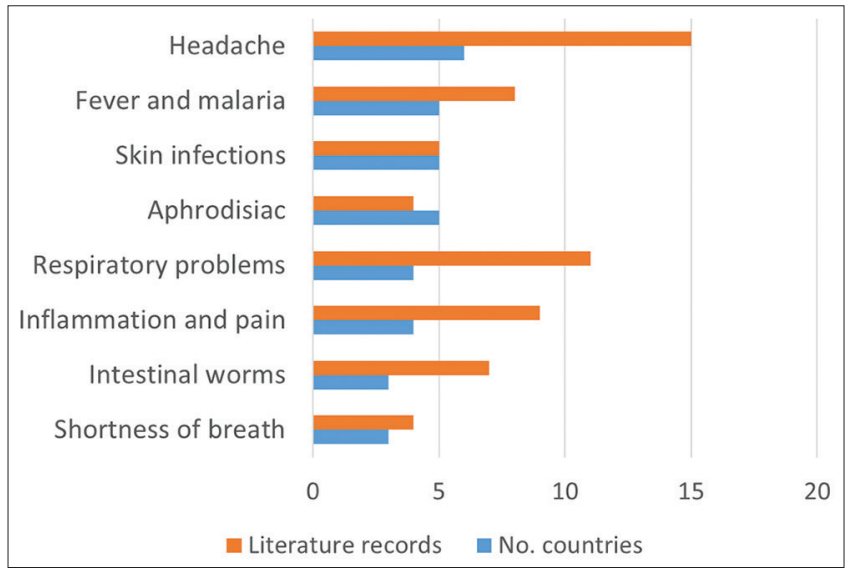

Fig. 1: Main medicinal uses of Heteromorpha arborescens in tropical Africa

\section{Anthelmintic activities}

McGaw et al. [68] evaluated anthelmintic activities of hexane, ethanol, and waterleaf extracts of $H$. arborescens on the mortality and reproductive ability of the free-living nematode Caenorhabditis elegans 
Table 2: Essential oil, total flavonoids, and phenolics content of Heteromorpha arborescens

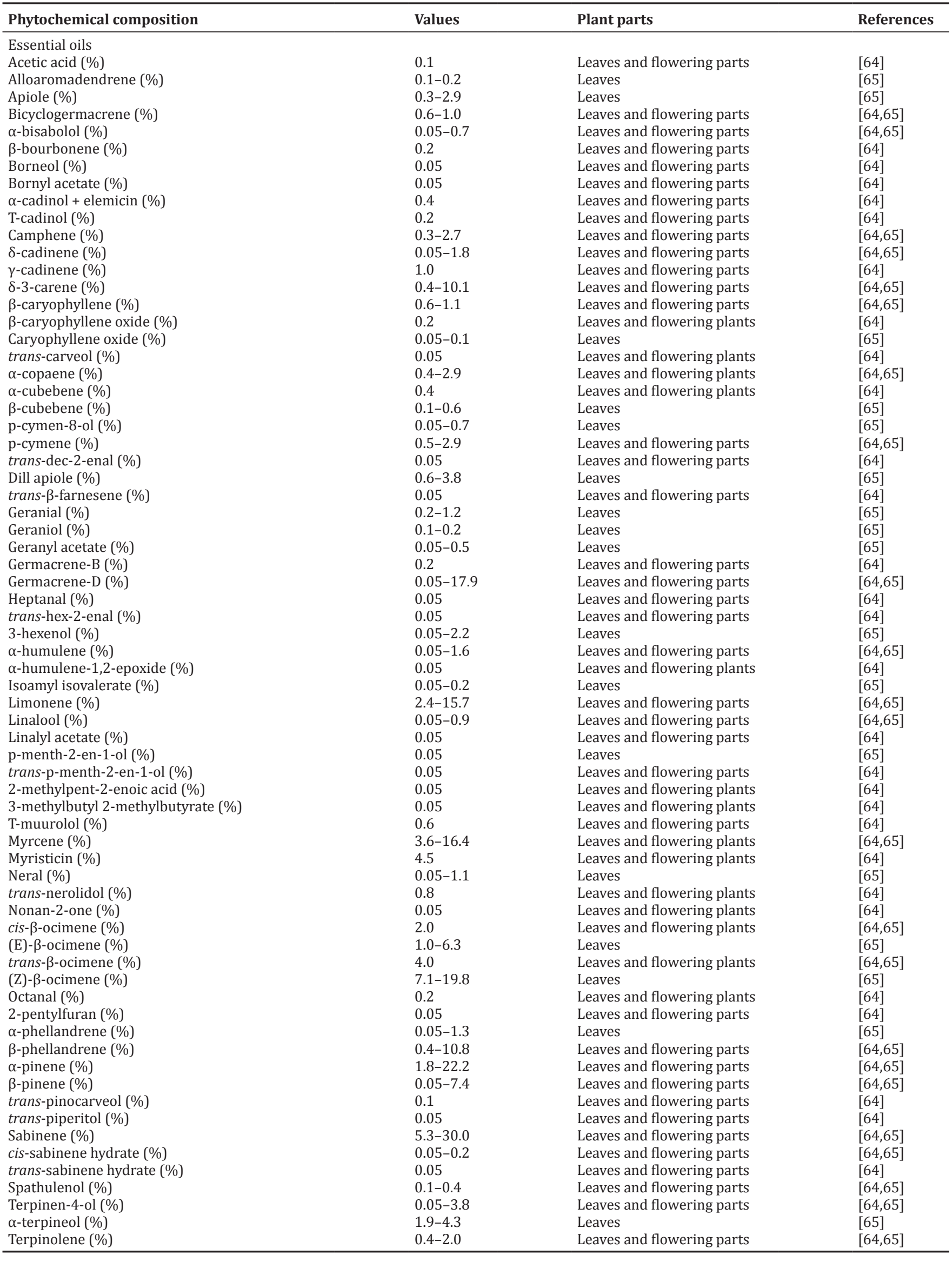


Table 2: (Continued)

\begin{tabular}{|c|c|c|c|}
\hline Phytochemical composition & Values & Plant parts & References \\
\hline$\alpha$-terpinene (\%) & $0.2-0.9$ & Leaves and flowering parts & {$[64,65]$} \\
\hline$\gamma$-terpinene $(\%)$ & $0.05-3.0$ & Leaves and flowering plants & {$[64,65]$} \\
\hline$\alpha$-thujene $(\%)$ & 0.1 & Leaves and flowering plants & {$[64,65]$} \\
\hline Torreyol (\%) & 0.05 & Leaves and flowering plants & [64] \\
\hline trans-sabinene hydrate (\%) & $0.05-0.2$ & Leaves & [65] \\
\hline Tricyclene (\%) & 0.05 & Leaves and flowering plants & [64] \\
\hline cis-verbenol (\%) & 0.1 & Leaves and flowering plants & [64] \\
\hline Total flavonoid content (mg QE/g) & $275.5 \pm 5.0$ & Leaves & [67] \\
\hline Total phenolic content (mg gallic acid equivalent/g) & $255.5 \pm 4.6$ & Leaves & [67] \\
\hline
\end{tabular}

in two different assays. Ethanol and water extracts exhibited activities at concentrations of $2 \mathrm{mg} / \mathrm{ml}$ after $2 \mathrm{~h}$ and the 7 -day incubation periods [68]. Adamu et al. [69] evaluated anthelmintic activities of leaf acetone extracts of $H$. arborescens using the egg hatch assay and the larval development test on the helminth, Haemonchus contortus. The extracts exhibited activities with median effective concentration $\left(\mathrm{EC}_{50}\right)$ values of $0.62 \mathrm{mg} / \mathrm{ml}$ for the egg hatch assay and $\mathrm{EC}_{50}$ value of $0.64 \mathrm{mg} / \mathrm{ml}$ in the larval development assay. The extracts resulted in $100 \%$ inhibition at concentrations as low as $3.13 \mathrm{mg} / \mathrm{ml}$ and the best inhibitory activity was at $0.39 \mathrm{mg} / \mathrm{ml}$ with $36.3 \%$ inhibition. The activities in the larval development test were generally lower than the egg hatch assay [69]. Adamu et al. [70] evaluated the anthelmintic activities of crude, butanol, ethyl acetate, chloroform, and hexane leaf extracts of $H$. arborescens using the egg hatch assay and the larval development test on the helminth, Haemonchus contortus. The extracts exhibited activities with $\mathrm{EC}_{50}$ values of $0.6 \mathrm{mg} / \mathrm{ml}$ to $2.9 \mathrm{mg} / \mathrm{ml}$ for the egg hatch assay and $\mathrm{EC}_{50}$ values of $0.6 \mathrm{mg} / \mathrm{ml}$ to $3.3 \mathrm{mg} / \mathrm{ml}$ in the larval development assay [70]. These anthelmintic activities exhibited by $H$. arborescens extracts corroborate the traditional usage of leaves and roots of the species against intestinal worms in Lesotho [35], South Africa [3,6,16,30,36], and Swaziland [11].

\section{Antiarthritic activities}

Elisha et al. [67] evaluated the antiarthritic activities of acetone leaf extracts of $H$. arborescens using an anti-protein denaturation assay. The extracts exhibited good in vitro antiarthritic activities with half maximal inhibitory concentration $\left(\mathrm{IC}_{50}\right.$ ) value of $53.8 \mu \mathrm{g} / \mathrm{ml}$ which was comparable to the $\mathrm{IC}_{50}$ value of $32.4 \mu \mathrm{g} / \mathrm{ml}$ exhibited by the positive control diclofenac sodium [67]. The promising activities of the extracts support the traditional claims of use of the species as remedies for rheumatism and other chronic inflammatory conditions.

\section{Antibacterial activities}

Desta [51] evaluated antibacterial activities of aqueous, dichloromethane, methanol, and petroleum ether milky exudate extracts of $H$. arborescens against Staphylococcus aureus, Salmonella gallinarum, Escherichia coli, Proteus vulgaris, Pseudomonas aeruginosa, and Klebsiella pneumoniae using the agar plate well diffusion method with neomycin as a positive control. Aqueous, dichloromethane, and methanol extracts exhibited activities against $S$. aureus, S. gallinarum, $E$. coli, and $P$. aeruginosa, with the zone of inhibition exhibited by the aqueous extract against $S$. aureus greater than that of neomycin, the standard antibiotic [51]. Deans et al. [66] evaluated antibacterial activities of the essential oil isolated from $H$. arborescens against 25 bacterial species. The essential oil exhibited activities against all tested microbes with zone of inhibition ranging from $4.0 \mathrm{~mm}$ to $15.3 \mathrm{~mm}$ [66]. McGaw et al. [68] evaluated antibacterial activities of hexane, ethanol, and waterleaf extracts of $H$. arborescens against Bacillus subtilis, S. aureus, E. coli, and Klebsiella pneumoniae using the disc diffusion assay and microdilution assay. Only ethanol extract exhibited activities with minimum inhibitory concentration (MIC) value of $0.78 \mathrm{mg} / \mathrm{ml}$ [68]. Nkomo and Kambizi [47] also evaluated the antibacterial activities of methanol and water root extracts of H. arborescens against Bacillus cereus, E. coli, K. pneumoniae, Micrococcus kristinae, P. aeruginosa, Serratia marcescens, Shigella flexneri, S. aureus,
Staphylococcus epidermidis, and Streptococcus faecalis. The methanolic extracts were active against all the bacterial strains with MIC values ranging from $0.1 \mathrm{mg} / \mathrm{ml}$ to $10.0 \mathrm{mg} / \mathrm{ml}$ while water extracts were active against $M$. kristinae, $S$. aureus, and $S$. epidermidis with MIC values ranging from $0.1 \mathrm{mg} / \mathrm{ml}$ to $10.0 \mathrm{mg} / \mathrm{ml}$ [47]. Adamu et al. [71] evaluated the antibacterial activities of the leaf acetone extract of $H$. arborescens against S. aureus, P. aeruginosa, E. coli, and Enterococcus faecalis using a serial microdilution method with gentamicin as the positive control. The extracts exhibited activities with MIC values ranging from $0.63 \mathrm{mg} / \mathrm{ml}$ to $1.25 \mathrm{mg} / \mathrm{ml}$ [71]. Adamu et al. [70] evaluated antibacterial activities of butanol, ethyl acetate, chloroform, and hexane leaf extracts of $H$. arborescens against $S$. aureus, E. faecalis, $P$. aeruginosa, and $E$. coli using a serial microplate dilution method with gentamicin as a positive control. The extracts showed activities with MIC values ranging from $0.16 \mathrm{mg} / \mathrm{ml}$ to $2.5 \mathrm{mg} / \mathrm{ml}$ and gentamicin, the control exhibited MIC value of $0.01 \mathrm{mg} / \mathrm{ml}$ [70]. Elisha et al. [72] evaluated the antibacterial activities of acetone leaf extracts of $H$. arborescens against Bacillus anthracis Sterne strain using the microplate serial dilution method with gentamicin as a positive control. The extracts exhibited activities with MIC value of $0.2 \mathrm{mg} / \mathrm{ml}$ and total antibacterial activity of $163 \mathrm{ml} / \mathrm{g}$ [72]. Elisha et al. [73] evaluated the antibacterial activities of acetone leaf extracts of $H$. arborescens against $S$. aureus, E. faecalis, B. cereus, E. coli, Salmonella typhimurium, and P. aeruginosa using a microplate serial dilution technique with gentamicin as the positive control. The extracts exhibited activities with MIC values ranging from $0.16 \mathrm{mg} / \mathrm{ml}$ to $0.52 \mathrm{mg} / \mathrm{ml}$ [73]. Elisha et al. [74] evaluated the antibacterial activities of acetone leaf extracts of $H$. arborescens against Stenotrophomonas maltophilia, K. pneumoniae, Salmonella serotype Typhimurium, Proteus mirabilis, Enterobacter cloacae, and E. coli using a serial microdilution method with gentamicin as a positive control. The extract exhibited activities with MIC values ranging from $0.08 \mathrm{mg} / \mathrm{ml}$ to $0.31 \mathrm{mg} / \mathrm{ml}$ and total antibacterial activity values ranging from $84.0 \mathrm{ml} / \mathrm{g}$ to $325.4 \mathrm{ml} / \mathrm{g}$ [74]. These antibacterial activities exhibited by extracts of $H$. arborescens support the traditional usage of the species as remedy for diseases caused by bacterial pathogens such as boils [40], dysentery [3,6,32,36], gonorrhea [51], skin infections [39], and stomach problems $[6,16,46]$.

\section{Antimycobacterial activities}

Madikizela and McGaw [75] evaluated the antimycobacterial activities of aqueous, acetone, and ethanol leaf extracts of $H$. arborescens against Mycobacterium aurum, Mycobacterium bovis, M. bovis BCG, Mycobacterium gordonae, Mycobacterium fortuitum, Mycobacterium smegmatis, Mycobacterium tuberculosis, and M. tuberculosis H37RV using a microdilution method. The extracts showed activities against tested pathogens with MIC values ranging from $0.08 \mathrm{mg} / \mathrm{ml}$ to $5.0 \mathrm{mg} / \mathrm{ml}$ [75]. These antimycobacterial activities exhibited by $H$. arborescens extracts corroborate medicinal usage of the species as herbal medicine for tuberculosis in both humans and animals [3,30,37,59].

\section{Antifungal activities}

Research by Villegas et al. [61] revealed that the petroleum ether leaf extract of $H$. arborescens was fungicidal in a TLC bioassay for Cladosporium cucumerium. The two compounds, falcarindiol and sarisan isolated from the leaves of $H$. arborescens were active to a concentration 
of $0.5 \mu \mathrm{g}$ in C. cucumerium bioassay [61]. Desta [51] evaluated antifungal activities of aqueous, dichloromethane, methanol, and petroleum ether milky exudate extracts of $H$. arborescens against Candida albicans using the agar plate well diffusion method with nystatin as a positive control. The aqueous and methanol extracts showed weak-to-moderate activities with zone of inhibition smaller than that exhibited by nystatin [51]. Deans et al. [66] evaluated antifungal activities of the essential oil isolated from $H$. arborescens against Aspergillus flavus, Aspergillus niger, Aspergillus ochraceus, and Aspergillus parasiticus. The essential oil exhibited activities against all tested microbes [66]. Nkomo and Kambizi [47] evaluated the antifungal activities of methanol and water root extracts of H. arborescens against Aspergillus flavus, A. niger, C. albicans, and Penicillium notatum. Both extracts did not show any activities against $C$. albicans, but extracts exhibited activities against $P$. notatum, A. flavus, and A. niger with medium lethal concentration $\left(\mathrm{LC}_{50}\right)$ values ranging from 0.1 to 3.2 [47]. Adamu et al. [76] evaluated antifungal activities of acetone leaf extracts of $H$. arborescens against Aspergillus fumigatus, Cryptococcus neoformans, and C. albicans using the serial microplate dilution method. The extracts exhibited activities with MIC values ranging from $0.16 \mathrm{mg} / \mathrm{mL}$ to $1.25 \mathrm{mg} / \mathrm{mL}$ [76]. Adamu et al. [70] evaluated antifungal activities of crude, butanol, ethyl acetate, chloroform, and hexane leaf extracts of $H$. arborescens against C. albicans, Candida neoformans, and Aspergillus fumigatus using the serial microplate dilution method with amphotericin B as a positive control. The extracts showed activities with MIC values ranging from $0.08 \mathrm{mg} / \mathrm{ml}$ to $2.5 \mathrm{mg} / \mathrm{ml}$ and amphotericin $\mathrm{B}$, the control exhibited MIC value of $0.01 \mathrm{mg} / \mathrm{ml}$ [70].These antifungal activities exhibited by $H$. arborescens extracts validate the traditional use of the species against fungal infections and ringworm in South Africa and Tanzania [33,42].

\section{Antiviral activities}

Beuscher et al. [77] evaluated the antiviral activities of dichloromethane, ethanol, and methanol root bark extracts of $H$. arborescens against poliovirus, herpes simplex virus, and rhinovirus using the plaque reduction assays. The ethanol and methanol extracts showed activities against poliovirus at a concentration range of $10 \mu \mathrm{g} / \mathrm{ml}$ to $50 \mu \mathrm{g} / \mathrm{ml}$ while dichloromethane extract showed activities against rhinovirus at a concentration range of $25 \mu \mathrm{g} / \mathrm{ml}-50 \mu \mathrm{g} / \mathrm{ml}$ [77].

\section{Anti-inflammatory activities}

Recio et al. [78] evaluated anti-inflammatory activities of methanol leaf and ethanol stem bark extracts of $H$. arborescens by administering extracts topically on tetradecanoylphorbol acetate (TPA)-induced mouse ear edema and orally on carrageenan-induced mouse paw edema. Theleaf and stem bark extracts were active when assayed topically (ear edema test) showing a percentage reduction in edema of $64 \%$ and $77 \%$, respectively. $3 \mathrm{~h}$ after carrageenan injection, the methanol leaf extracts showed antiinflammatory activities with a percent reduction in edema of 44\% [78]. Similarly, Recio et al. [62] evaluated anti-inflammatory activities of two saikosaponins isolated from methanol extracts of $H$. arborescens leaves, 16 $\beta, 23$-dihydroxy-13,28-epoxyolean-11-en-3 $\beta$-yl-[ $\beta$-D-glucopyranosyl $(1 \rightarrow 2)]$-[ $\beta$-D-glucopyranosyl $(1 \rightarrow 3)]-\beta$-D-fucopyranoside and $16 \beta, 23,28$ trihydroxy-11 $\alpha$-methoxyolean-12-en-3 $\beta$-yl-[ $\beta$-D-glucopyranosyl $(1 \rightarrow 2)]$-[ $\beta$-D-glucopyranosyl $(1 \rightarrow 3)]-\beta$-D-fucopyranoside using TPAinduced mouse ear edema assay, ethylphenylpropiolate (EPP) mouse ear edema, the serotonin paw edema, and carrageenan paw edema tests. The compound 16 $\beta, 23$-dihydroxy-13,28-epoxyolean-11-en$3 \beta$-yl-[ $\beta$-D-glucopyranosyl ( $1 \rightarrow 2)]$-[ $\beta$-D-glucopyranosyl $(1 \rightarrow 3)]-\beta-D-$ fucopyranoside showed activity in the TPA, EPP, and the serotonin paw

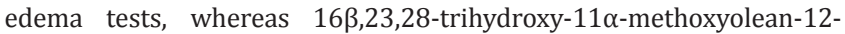
en-3 $\beta$-yl-[ $\beta$-D-glucopyranosyl $(1 \rightarrow 2)]-[\beta$-D-glucopyranosyl $(1 \rightarrow 3)]-\beta$-Dfucopyranoside was active only in the mouse ear edema model. Both compounds had only a slight effect against a carrageenan paw edema model [62]. McGaw et al. [41] assessed anti-inflammatory activities of aqueous and ethanol leaf extracts of $H$. arborescens by evaluating the presence of prostaglandin synthesis inhibitors using the cyclooxygenase-1 (COX-1) assay. An ethanolic extract exhibited good COX-1 inhibitory activities (85-88\%), whereas water extract was less active $(32-75 \%)$ in comparison to $75 \%$ inhibitory activity exhibited by the standard indomethacin $(0.5 \mu \mathrm{g})$ [41]. Lundgaard et al. [32] evaluated the COX-1 inhibition activities of acetone, aqueous, dichloromethane, ethyl acetate, methanol, and petroleum ether root, bark, and leaf extracts of $H$. arborescens using the COX-1 assay. The organic extracts of roots had good activities, the petroleum ether extract of the twigs also had high inhibitory activities, while the leaves, in general, did not show much activity and water extracts of all the three plant parts were inactive [32]. Nkomo et al. [79] evaluated the anti-inflammatory activities of aqueous and methanol root extracts of $H$. arborescens using inflammatory pain assay, the albumin-induced hind paw edema model, and the carrageenaninduced hind paw edema model. Both extracts produced a significant reduction of edema induced by albumin and carrageenan [79]. Elisha et al. [67] evaluated the anti-inflammatory activities of acetone leaf extracts of $H$. arborescens by determining the inhibition of nitric oxide production in lipopolysaccharide-activated RAW 264.7 macrophages as well as 15-lipoxygenase enzyme inhibition. The extracts inhibited nitric oxide production in a dose-dependent manner in the LPS-stimulated RAW 264.7 macrophages with $H$. arborescens inhibiting NO production by $89.5 \%$ at a concentration of $30 \mu \mathrm{g} / \mathrm{ml}$. The extract exhibited weak activities against 15-lipoxygenase activity with $\mathrm{IC}_{50}$ value of $85.0 \mu \mathrm{g} / \mathrm{ml}$ which was higher than $\mathrm{IC}_{50}$ value of $53.7 \mu \mathrm{g} / \mathrm{ml}$ exhibited by the positive control quercetin [67]. These findings seem to justify the use of the plant in traditional medicine in the management of pain and inflammationrelated diseases such as painful joints, rheumatism, abdominal, back, and general body pains [3-6,11,29-32].

\section{Antinociceptive activities}

Nkomo et al. [79] evaluated the antinociceptive activities of aqueous and methanol root extracts of $H$. arborescens using the hot plate, abdominal constriction, and formalin tests. Both extracts produced significant inhibition of thermal nociception induced by a hot plate. On chemical nociception induced by intraperitoneal acetic acid and subplantar formalin injection, both extracts significantly decreased the number of writhing episodes and the licking time in a dose-dependent manner. Treatment with the extracts at the same doses produced a significant pain inhibition of the carrageenan-induced inflammatory pain [79]. These findings seem to justify the use of the plant in traditional medicine in the management of pain and inflammation-related diseases.

\section{Antioxidant activities}

Adamu et al. [71] evaluated the antioxidant activities of the leaf acetone extract of $H$. arborescens using the 2,2-diphenyl-1-picrylhydrazyl (DPPH) and 2,2'-azino-bis (3-ethyl-benzthiazoline-6-sulfonic acid) radical scavenging assays. The extract exhibited trolox equivalent antioxidant capacity (TEAC) value of 0.2 and $\mathrm{EC}_{50}$ value of 4.4 using ABTS and DPPH, respectively [71]. Elisha et al. [67] evaluated the antioxidant activities of acetone leaf extracts of $H$. arborescens using the DPPH and ABTS radical scavenging assays and ferric reducing antioxidant power (FRAP) assay. The extracts showed weak antioxidant activity with IC s0 $_{50}$ value of $154.8 \mu \mathrm{g} / \mathrm{ml}$ which was much higher than IC $_{50}$ values of $3.3 \mu \mathrm{g} / \mathrm{ml}$ and $5.6 \mu \mathrm{g} / \mathrm{ml}$ exhibited by ascorbic acid and trolox, respectively, the two positive controls. The $\mathrm{IC}_{50}$ values for ABTS assay were $95.7 \mu \mathrm{g} / \mathrm{ml}$ with ascorbic acid and trolox exhibiting IC $_{50}$ values of $2.9 \mu \mathrm{g} / \mathrm{ml}$ and $6.8 \mu \mathrm{g} / \mathrm{ml}$, respectively. The TEAC and FRAP values were 0.07 and 0.06 , respectively [67]

\section{Anti-peptic ulcer activities}

Osim et al. [80] evaluated the effects of $H$. arborescens aqueous root bark extract on acetic acid-induced ulcers, food intake, water intake, weight gain, and gastric acid secretion in female Sprague-Dawley rats. Following consumption of the extract, food intake, daily water intake, and weekly weight gain were not significantly different in the test and control groups. The extract had no significant effect on gastric acid secretion stimulated by histamine, gastrin, and carbachol. However, histological examination revealed traces of ulcer at the sites where ulcers were induced previously. Osim et al. [80] concluded that $H$. arborescens accelerates the healing of acetic acid-induced peptic ulcer in rats. These findings validate the use of $H$. arborescens in the treatment of peptic ulcer in humans in Kenya [56] and Zimbabwe [57]. 


\section{Anti-scabies activities}

Heyndrickx et al. [38] evaluated anti-scabies activities of chloroform, ethanol, hexane, and waterleaf extracts of $H$. arborescens against the larvae, nymphae, and adult Psoroptes cuniculi with lindane as a positive control. Only chloroform extract at a concentration of $1 \mu \mathrm{gcm}^{2}$ exhibited $100 \%$ morality and the control, lindane also showed $100 \%$ morality [38]. These findings corroborate the traditional usage of $H$. arborescens leaves as herbal medicines against scabies in Rwanda [38]

\section{Antispasmodic activities}

Parry et al. [56] investigated the antispasmodic activities of aqueous root bark extract of $H$. arborescens on various smooth gastrointestinal muscle preparations performed on the isolated guinea pig ileum preparation. The extract had no contractile or relaxant effect on guinea pig gastrointestinal smooth muscle, trachea, and tenia coli nor did it affect the spontaneously beating atrium. However, the extract antagonized ileal contractions induced by acetylcholine, histamine, serotonin, and potassium chloride in a concentration-dependent manner. The extracts antagonize the effects of various agonists by either preventing calcium influx into the smooth muscle cell or inhibiting the calcium-induced calcium release mechanism or preventing the release of calcium from the sarcoplasmic reticulum or by preventing the binding of calcium to calmodulin [56]. These findings could explain its rational use in traditional medicine to alleviate abdominal spasms.

\section{Uterotonic activities}

Katerere and Parry [81] evaluated the uterotonic activities of aqueous root bark extract of $H$. arborescens on Sprague-Dawley rat uterine and skeletal muscles. The extract contracted the rat uterus and the contractions were not antagonized by atropine but were blocked by both cyproheptadine and verapamil. The extract also induced a contracture of the rat diaphragm muscle in the presence of alcuronium. The contractile effects on the uterus appear to involve stimulation of serotonin $\mathrm{HT}_{2}$ receptors, leading to an increase in calcium influx into the smooth muscle cell [81].

\section{Cytotoxicity activities}

Adamu et al. [69] evaluated cytotoxicity activities of leaf acetone extracts of $H$. arborescens using the 3-5-dimethyl thiazol-2-yl-2, 5-diphenyl tetrazolium bromide (MTT) cellular assay. The extracts exhibited moderate toxicity with $\mathrm{LC}_{50}$ value of $0.04 \mathrm{mg} / \mathrm{ml}$ and selectivity index value of 0.07 [69]. Adamu et al. [70] evaluated cytotoxicity activities of crude, butanol, ethyl acetate, chloroform, and hexane leaf extracts of H. arborescens using the MTT assay on Vero cells with berberine chloride (Sigma) as a positive control. The $\mathrm{EC}_{50}$ values exhibited by the extracts ranged from $0.04 \mathrm{mg} / \mathrm{ml}$ to $2.1 \mathrm{mg} / \mathrm{ml}$ [70]. Elisha et al. [73] evaluated the cytotoxicity activities of acetone leaf extracts of $H$. arborescens on Vero kidney cells using the MTT reduction assay with doxorubicin as a positive control. The extract was non-toxic with $\mathrm{LC}_{50}$ value of $81.0 \mu \mathrm{g} / \mathrm{ml}$ which was much higher than $\mathrm{LC}_{50}$ value of $8.3 \mu \mathrm{g} / \mathrm{ml}$ exhibited by the control doxorubicin [73]. Elisha et al. [74] evaluated the cytotoxicity activities of acetone leaf extracts of $H$. arborescens using the MTT assay on Vero cells with doxorubicin as a positive control. The extracts exhibited $\mathrm{LC}_{50}$ value of $81.0 \mu \mathrm{g} / \mathrm{ml}$ and therefore considered to be non-toxic in comparison to the reference drug doxorubicin which exhibited $\mathrm{LC}_{50}$ value of $8.3 \mu \mathrm{g} / \mathrm{ml}$ [74]. Madikizela and McGaw [63] evaluated the cytotoxicity activities of aqueous and ethanol leaf extracts of $H$. arborescens against Vero monkey kidney and bovine dermis cells using the MTT assay. The tested extracts were non-cytotoxic against both Vero and bovine dermis cells with $\mathrm{LC}_{50}$ values ranging from $0.9 \mathrm{mg} / \mathrm{ml}$ to $5.6 \mathrm{mg} / \mathrm{ml}$, and the selectivity index values ranging from 1.3 to 69.9 [63].

\section{Genotoxicity activities}

Madikizela and McGaw [75] evaluated the genotoxicity activities of aqueous, acetone, and ethanol leaf extracts of $H$. arborescens against Salmonella typhimurium TA98 and TA100. The ethanol extracts showed clear mutagenicity against TA100 with numbers of revertant colonies greater than twice that of the negative controls for the $5 \mathrm{mg} / \mathrm{ml}$, the highest concentration tested, however, decreasing with decreasing concentrations of extracts [75].

\section{CONCLUSION}

H. arborescens is an important medicinal plant species throughout its distributional range in tropical Africa. The pharmacological evaluations carried so far, corroborate some of the documented medicinal uses of the species. There are still research gaps regarding phytochemistry of the species and it, therefore, seems premature to draw firm conclusions about the alleged therapeutic effects of $H$. arborescens. Previous research by Maroyi [82] and Zaidi et al. [83] revealed that the development of pharmaceutical drugs and health-promoting products from herbal medicines is a complicated process. Therefore, more detailed research is needed aimed at assessing several plant parts of the species used as traditional medicines, evaluating their chemical compounds, biological, and toxicological activities. Detailed clinical trials are also required aimed at evaluating the efficacy of crude extracts of $H$. arborescens or compounds isolated from the species.

\section{ACKNOWLEDGMENTS}

The author would like to express his gratitude to the National Research Foundation (NRF), South Africa and Govan Mbeki Research and Development Centre (GMRDC), University of Fort Hare for financial support to conduct this study.

\section{AUTHOR'S CONTRIBUTION}

The author declares that this work was done by the author named in this article.

\section{CONFLICTS OF INTEREST}

The author declares that there are no conflicts of interest regarding the publication of this paper.

\section{REFERENCES}

1. Van Wyk BE. A review of African medicinal and aromatic plants. In: Neffati M, Najjaa H, Máthé Á, editors. Medicinal and Aromatic Plants of the World: Africa. Dordrecht: Springer; 2017. p. 19-60.

2. Van Wyk BE. The potential of South African plants in the development of new medicinal products. S Afr J Bot 2011;77:812-29.

3. Watt JM, Breyer-Brandwijk MG. The Medicinal and Poisonous Plants of Southern and Eastern Africa. Edinburgh: E and S Livingstone Ltd.; 1962.

4. Gelfand M, Mavi S, Drummond RB, Ndemera B. The Traditional Medical Practitioner in Zimbabwe: His Principles of Practice and Pharmacopoeia. Gweru: Mambo Press; 1985.

5. Hutchings A, Scott AH, Lewis G, Cunningham AB. Zulu Medicinal Plants: An Inventory. Pietermaritzburg: University of Natal Press; 1996.

6. Van Wyk BE, Van Oudtshoorn B, Gericke N. Medicinal Plants of South Africa. Pretoria: Briza Publications; 2013.

7. Setshogo MP, Mbereki CM. Floristic diversity and uses of medicinal plants sold by street vendor in Gaborone, Botswana. Afr J Pl Sci Biotechnol 2011;5:69-74.

8. Meke GS, Mumba RF, Bwanali RJ, Williams VL. The trade and marketing of traditional medicines in Southern and Central Malawi. Int J Sustain Dev World Ecol 2017;24:73-87.

9. Botha J, Weiersbye IM. Ethnobotanic and forage uses of plants on mine properties in the Witwatersrand basin gold fields, South Africa. In: Fourie A, Tibbett M, Wiertz J, editors. Mine Closure. Perth: Australian Centre for Geomechanics; 2010. p. 325-42.

10. Bussmann RW. Ethnobotany of the samburu of Mt. Nyiru, South Turkana, Kenya. J Ethnobiol Ethnomed 2006;2:35.

11. Long C. Swaziland's Flora: SiSwati Names and uses. Swaziland National Trust Commission; 2005. Available from: http://www.sntc. Org.sz/index.asp. [Last accessed on 2018 May 21].

12. Winter PJ, Van Wyk BE. A revision of the genus Heteromorpha. Kew Bull 1996;51:225-65.

13. Calviño CI, Tilney PM, Wyk BE, Downie SR. A molecular phylogenetic study of Southern African Apiaceae. Am J Bot 2006;93:1828-47.

14. Van Wyk AE, Van Wyk P. Field Guide to Trees of Southern Africa. Cape Town: Struik Publishers (Pty) Ltd.; 1997.

15. Palgrave MC. Keith Coates Palgrave Trees of Southern Africa. $3^{\text {rd }}$ ed. Cape Town: Struik Publishers (Pty) Ltd.; 2002.

16. Schmidt E, Lotter M, McCleland W. Trees and Shrubs of Mpumalanga and Kruger National Park. Johannesburg: Jacana; 2002.

17. Cannon JF. Umbelliferae. Conspectus Fl Angol 1970;4:340-3 
18. Cannon JF. Umbelliferae. In: LaunertE, editor. Flora Zambesiaca 4. London: Flora Zambesiaca Managing Committee; 1978. p. 578-81.

19. Townsend CC. Some notes on species of Heteromorpha (Umbelliferae). Kew Bull 1985;40:843-50.

20. Townsend CC. Umbelliferae. In: Polhill RM, editor. Flora of Tropical East Africa. Rotterdam: A.A. Balkema; 1989. p. 37-41.

21. Winter PJ, Van Wyk BE, Tilney PM. The morphology and development of the fruit of Heteromorpha (Apiaceae). S Afr J Bot 1993;59:336-41.

22. Winter PJ, Van Wyk BE. The taxonomic value of epidermal characters in the leaf of Heteromorpha and some related genera (Apiaceae). Bothalia 1994;24:187-94.

23. Setshogo MP, Venter F. Trees of Botswana: Names and Distribution. Pretoria: Southern African Botanical Diversity Network Report No. 18; 2003.

24. Da Silva MC, Izidine S, Amude AB. A Preliminary Checklist of the Vascular Plants of Mozambique. Pretoria: Southern African Botanical Diversity Network Report No. 30; 2004.

25. Burrows JE, Willis CK. Plants of the Nyika Plateau. Pretoria: Southern African Botanical Diversity Network Report No. 31; 2005.

26. Phiri PSM. A Checklist of Zambian Vascular Plants. Pretoria: Southern African Botanical Diversity Network Report No. 32; 2005.

27. Setshogo MP. Preliminary Checklist of the Plants of Botswana. Pretoria: Southern African Botanical Diversity Network Report No. 33, SABONET; 2005

28. Hyde MA, Wursten BT, Ballings P, Palgrave CM. Heteromorpha arborescens (Spreng.) Cham. Schltdl. Var. Abysinica (A. Rich.) H. Wolff. Flora of Zimbabwe: Species Information: Heteromorpha arborescens var. Abyssinica; 2018. Available from: https://www. zimbabweflora.co.zw/speciesdata/species.php?species_id=143100. [Last retrieved on $2018 \mathrm{Apr} 21]$.

29. Arnold HJ, Gulumian M. Pharmacopoeia of traditional medicine in Venda. J Ethnopharmacol 1984;12:35-74.

30. Bryant AT. Zulu Medicine and Medicine-Men. Cape Town: C. Struik; 1966.

31. McGaw LJ, JägerAK, Van Staden J. Prostaglandin synthesis inhibitory activity in zulu, xhosa and sotho medicinal plants. Phytother Res 1997;11:113-7.

32. Lundgaard NH, Prior RM, Light ME, Stafford GI, Van Staden J, Jäger AK. COX-1 inhibition of Heteromorpha arborescens. Safr J Bot 2008;74:335-7

33. Palmer E, Pitman P. Trees for Southern Africa Covering all Known Indigenous Species in Republic of South Africa, South West Africa, Botswana, Lesotho and Swaziland. Cape Town: A.A. Balkema; 1972.

34. Spencer P. Samburu Notions of Health and Disease, and their Relationship to Inner Cleanliness. SOAS Research Online, No 8764; 1959. Available from: https://www.eprints.soas.ac.uk. [Last retrieved on 2018 Apr 07]

35. Jacot-Guillarmod A. Flora of Lesotho. Lehre: J Cramer; 1971.

36. Van Wyk BE, Gericke N. People's Plants: A Guide to Useful Plants of Southern Africa. Pretoria: Briza Publications; 2007.

37. Madikizela B, Kambizi L, McGaw LJ. An ethnobotanical survey of plants used traditionally to treat tuberculosis in the eastern region of O.R. Tambo district, South Africa. S Afr J Bot 2017;109:231-6.

38. Heyndrickx G, BrioenP, Van Puyvelde L. Study of Rwandese medicinal plants used in the treatment of scabies. J Ethnopharm 1992;35:259-62.

39. Ngari EW, Chiuri LW, Kariuki ST, Huckett S. Ethnomedicine of Ogiek of river Njorowatershed, Nakuru, Kenya. Ethnobot Res Appl 2010;8:135-52

40. Maregesi SM, Mwakalukwa R. Ethnopharmacological study on medicinal plants used to treat infectious diseases in the Rungwe district, Tanzania. Int J Med P1 Nat Prod 2015;1:15-23.

41. Sewani-Rusike CR. Plants of Zimbabwe used as anti-fertility agents. Afr J Tradit Complement Altern Med 2010;7:253-7.

42. Moshi MJ, Mbwambo ZH. Experience of Tanzanian traditional healers in the management of non-insulin dependent diabetes mellitus. Pharm Biol 2002;40:552-60.

43. Erasto P, Adebola PO, Grierson DS Afolayan AJ. An ethnobotanical study of plants used for the treatment of diabetes in the Eastern Cape Province, South Africa. Afr J Biotechnol 2005;4:1458-60.

44. Hedberg I, Staugård F. Traditional Medicine in Botswana: Traditional Medicinal Plants. Gaborone: Ipelegeng Publishers; 1989.

45. Yemane B, Medhanie G, Reddy KS. Survey of some common medicinal plants used in Eritrean folk medicine. Am J Ethnomed 2017;4:14.

46. Mabogo DE. The Ethnobotany of the Vhavenda. MSc Dissertation, Pretoria: University of Pretoria; 1990.

47. Nkomo M, Kambizi L. Antimicrobial activity of Gunnera perpensa and Heteromorpha arborescens var. Abyssinica. J Med P1 Res 2009;3:1051-5.

48. Msonthi JD, Hostettmann K, Maillard MR. Phytochemical Studies of
Medicinal Plants from Malawi. In: Hostettmann K, Chinyanganya F, Maillard MR, Wolfender JK, editors. Chemistry, Biological and Pharmacological Properties of African Medicinal Plants. Harare: University of Zimbabwe Publications; 1996. p. 171-86.

49. Fowler DG. Traditional Fever Remedies: Alist of Zambian Plants; 2006. Available from: http://www.giftsofhealth.org/ritam/news/Traditional Fever remedie1.pdf. [Last accessed on 2018 Mar 11].

50. Stangeland T, Alele PE, Katuura E, Lye KA. Plants used to treat malaria in Nyakayojo sub-county, Western Uganda. J Ethnopharm 2011;137:154-66.

51. Desta B. Ethiopian traditional herbal drugs. Part II: Antimicrobial activity of 63 medicinal plants. J Ethnopharmacol 1993;39:129-39.

52. Hutchings A, van Staden J. Plants used for stress-related ailments in traditional zulu, xhosa and sotho medicine. Part 1: Plants used for headaches. J Ethnopharmacol 1994;43:89-124.

53. Moteetee A, Van Wyk BE. The medical ethnobotany of Lesotho: A review. Bothalia 2011;41:209-28

54. Pujol J. Naturafrica: The Herbalist Handbook. Durban: Jean Pujol Natural Healers Foundation, Durban; 1990

55. Abebe D, Hagos E. Plants as a primary source of drugs in the traditional health practices of Ethiopia. In: Engles JMM, Hawkes JG, Worede M, editors. Plant Genetic Resources of Ethiopia. Cambridge: Cambridge University Press; 1991. p. 101-13.

56. Parry O, Duri ZJ, Zinyama E. The effects of Heteromorpha trifoliata on gastrointestinal smooth muscle of the guinea pig. J Ethnopharm 1996:54:13-7.

57. Okello SV, Nyunja RO, Netondo GW, Onyango JC. Ethnobotanical study of medicinal plants used by sabaots of Mt. Elgon Kenya. Afr J Tradit Complement Altern Med 2009;7:1-0.

58. Chekole G, Asfaw Z, Kelbessa E. Ethnobotanical study of medicinal plants in the environs of Tara-gedam and Amba remnant forests of Libo Kemkem district, Northwest Ethiopia. J Ethnobiol Ethnomed 2015;11:4.

59. Gerstner J. A preliminary checklist of Zulu names of plants with short notes. Bantu Stud 1938;12:215-36, 321-42.

60. Masika PJ, Van Averbeeke W, Sonandi A. Use of herbal remedies by small scale farmers to treat livestock diseases in central Eastern Cape Province, South Africa. J Safr Vet Assoc 2000;71:87-91.

61. Villegas M, Vargas D, Msonthi JD, Marston A, Hostetmann K. Isolation of antifungal compounds falcarindiol and sarisan from Heteromorph atrifoliata. Planta Med 1988;54:36-7

62. Recio MD, Just MJ, Giner RM, Manez S, Rios JL, Horstettmann K. Anti-inflammatory activity of saikosaponins from Heteromorph atrifoliata. J Nat Prod 1995;58:1404.

63. Makungo T, Van Ree T. Die aktiewe bestanddeel van wildepietersielie (Heteromorpha arborescens): 6,7-dimetoksikumarien. Suid Afr Tydskrif Nat Tegnol 2014;33:762.

64. Mwangi JW, Achola KJ, Lwande W, HassanaliA, Laurent R. Volatile components of Heteromorpha trifoliate (Wendl) Eckl. Zey. Flav Fragr J 1994;9:241-3

65. Chagonda LS, Makanda CD, Chalchat JC. Essential oils of cultivated Heteropyxis natalensis (Harv.) and Cultivated Heteromorpha trifoliata (Wendl.) Eckl. Zey. From Zimbabwe. J Essential Oil Res 2000;12:317-21.

66. Deans SG, Kennedy AI, Gundidza MG, Mavi S, Waterman PG, Gray AI. Antimicrobial activities of the volatile oil of Heteromorpha trifoliata (Wendl.) Eckl. And zeyh (Apiaceae). Flav Fragr J 1994;9:245-8.

67. Elisha IL, Dzoyem JP, McGaw LJ, Botha FS, Eloff JN. The antiarthritic, anti-inflammatory, antioxidant activity and relationships with total phenolics and total flavonoids of nine South African plants used traditionally to treat arthritis. BMC Complement Altern Med 2016;16:307.

68. McGaw LJ, Jäger AK, Van Staden J. Antibacterial, anthelmintic and anti-amoebic activity in South African medicinal plants. J Ethnopharm 2000;72:247-63

69. Adamu M, Naidoo V, Eloff JN. Efficacy and toxicity of thirteen plant leaf acetone extracts used in ethnoveterinary medicine in South Africa on egg hatching and larval development of Haemonchus contortus. BMC Vet Res 2013;9:38.

70. Adamu M, Bagla VP, Eloff JN. Fractionation of Heteromorpha arborescens Var abyssinica (Apiaceae) leaf extracts based on polarity leads to a marked change in cytotoxicity that may yield a commercially useful product. S Afr J Bot 2016;103:36-40.

71. Adamu M, Naidoo V, Eloff JN. The antibacterial activity, antioxidant activity and selectivity index of leaf extracts of thirteen South African tree species used in ethnoveterinary medicine to treat helminth infections. BMC Vet Res 2014;10:52

72. Elisha IL, Dzoyem JP, Botha FS, Eloff JN. The efficacy and safety of nine South African medicinal plants in controlling Bacillus anthracis 
sterne vaccine strain. BMC Complement Altern Med 2016;16:5.

73. Elisha IL, Botha FS, McGaw LJ, Eloff JN. The antibacterial activity of extracts of nine plant species with good activity against Escherichia coli against five other bacteria and cytotoxicity of extracts. BMC Complement Altern Med 2017;17:133.

74. Elisha IL, Jambalang AR, Botha FS, Buys EM, McGaw LJ, Eloff $\mathrm{JN}$, et al. Potency and selectivity indices of acetone leaf extracts of nine selected South African trees against six opportunistic Enterobacteriaceae isolates from commercial chicken eggs. BMC Complement Altern Med 2017;17:90.

75. Madikizela B, McGaw LJ. Scientific rationale for traditional use of plants to treat tuberculosis in the Eastern region of the OR Tambo district, South Africa. J Ethnopharmacol 2018;224:250-60.

76. Adamu M, Naidoo V, Eloff JN. Some Southern African plant species used to treat helminth infections in ethnoveterinary medicine have excellent antifungal activities. BMC Complement Altern Med 2012;12:213

77. Beuscher N, Bodinet C, Neumann-Haefelin D, Marston A, Hostettmann K. Antiviral activity of African medicinal plants. J Ethnopharm 1994;42:101-9.
78. Recio MD, Giner RM, Manez S, Rios JL, Horstettmann K. Screening of tropical plants for anti-inflammatory activity. Phytother Res 1995;9:571-4.

79. Nkomo M, Nkeh-Chungag BN, Kambizi L, Ndebia EJ, SewaniRusike C, Iputo JE, et al. Investigation of the antinociceptive and antiinflammatory properties of Heteromorpha arborescens (Apiaceae). Afr J Tradit Complement Altern Med 2011;8:412-9.

80. Osim EE, Maredza T, Rao PV, Nhandara B, Adeyanju B, et al. Heteromorpha trifoliata (Dombwe) accelerates acetic acid induced peptic ulcers: A preliminary study in the rats. Cent Afr J Med 1999; $45: 35-40$

81. Katerere D, Parry O. Pharmacological actions of Heteromorpha trifoliata ("dombwe") on rat isolated muscle preparations. Cent Afr J Med 2000;46:9-13.

82. Maroyi A. Dicoma anomala sond: A review of its botany, ethnomedicine, phytochemistry and pharmacology. Asian J Pharm Clin Res 2018;11:70-7.

83. Zaidi FB, Ahmed S, Makkad M. Role of effective project management in reducing drug development cost. Asian J Pharm Clin Res 2017;10:53-6. 